\title{
Half-and-half nails in a patient on antituberculosis treatment
}

\author{
Andrew Chadwick, ${ }^{1}$ Victoria Thwaites, ${ }^{2}$ Margaret Holland, ${ }^{3}$ Mitra Shahidi ${ }^{4}$
}

${ }^{1}$ Adult Intensive Care Unit, Oxford University NHS Trust, Oxford, UK

${ }^{2}$ Oxford University Hospitals NHS Foundation Trust, Oxford, Oxfordshire, UK

${ }^{3}$ Respiratory Department, Stoke Mandeville Hospital, Aylesbury, Buckinghamshire, UK

${ }^{4}$ Department of Respiratory Medicine, Stoke Mandeville Hospital, Aylesbury, UK

\section{Correspondence to} Dr Andrew Chadwick, achadwick@doctors.net.uk

Accepted 13 March 2017

\section{CrossMark}

To cite: Chadwick $A$, Thwaites $\mathrm{V}_{\text {, Holland } \mathrm{M}}$ et al. BMJ Case Rep Published online: [please include Day Month Year] doi:10.1136/bcr-2017219841

\section{DESCRIPTION}

A Nigerian-born British national aged 24 years presented to our tuberculosis (TB) clinic after a positive, screening, quantiFERON blood test. She had been in the country for 12 years, had no known exposure to $\mathrm{TB}$ and no previous medical history. She was counselled regarding the risks and benefits of treating latent $\mathrm{TB}$ and then, following normal liver and kidney function blood tests, was started on combined rifampicin and isoniazid. She returned 4 weeks later to follow-up clinic with no systemic symptoms or side effects but with nail changes as shown in figure 1.

The diagnosis is half-and-half nails, in this case caused by isoniazid, likely due to its effects on niacin metabolism. However, half-and-half nails are most commonly seen in renal failure, and therefore, renal function tests are critical part of the work-up.

Half-and-half nails are when the distal nail bed discolours to red-brown and the proximal nail bed becomes white. Importantly, the diagnosis requires that at least $20 \%$ of the distal nail should be redbrown, otherwise the diagnosis is Terry's nail. ${ }^{1}$ The pathogenesis of these nail changes is not understood, though melanin deposition in the nail plate may explain the red-brown discolouration. Thickening of the extracellular matrix between the nail and bone may lead to lower blood supply to
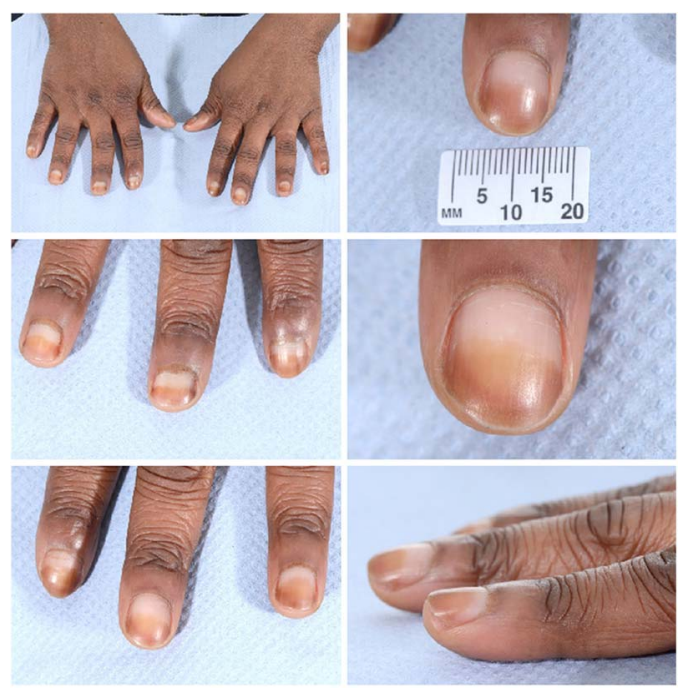

Figure 1 Photograph November 2015 showing the nail changes across all fingers and close up. the proximal nail and its whiter colour. The condition can occur in isolation, though it is also associated with renal failure, Bechet's disease, Crohn's disease and pellagra.

In our patient, the nail changes appeared with the isoniazid treatment, though interestingly she developed no other symptoms or signs in keeping with fulminant pellagra (the four D's of diarrhoea, dermatitis, dementia and death). This differentiates her case from two other case reports presenting half-and-half nails secondary to isoniazid. ${ }^{2}{ }^{3}$ Our patient was young, healthy and had no other symptoms or signs before, during or after her treatment with combined rifampicin and isoniazid. Furthermore, her nail changes have completely resolved since completion of her 3 months of therapy. She therefore constitutes a unique case highlighting a rare dermatological side effect of an increasingly common treatment. Indeed, it is no longer just rifampicin that can be blamed for changing elements of the body orange, or at least red-brown.

\section{Learning points}

Isoniazid can cause the isolated side effect of half-and-half nails without systemic changes.

- It is essential to check renal function in all patients presenting with half-and-half nails.

Contributors MS, MH and $A C$ were directly involved in the patient care. $\mathrm{AC}$ wrote the first draft of the article. MS and $\mathrm{MH}$ provided edits and further research on the article. VT then provided further research input and rewrote the article in line with BMJ Case reports formatting. All authors were then involved in the final review and editing of the case report.

Competing interests None declared.

Patient consent Obtained.

Provenance and peer review Not commissioned; externally peer reviewed.

\section{REFERENCES}

1 Iorizzo M, Daniel CR, Tosti A. Half and half nails: a past and present snapshot. Cutis 2011;88:138-9.

2 Ma Y, Xiang Z, Lin L, et al. Half-and-half nail in a case of isoniazid-induced pellagra. Postepy Dermatol Alergol 2014:31:329-31.

3 Cakmak SK, Gönül M, Aslan E, et al. Half-and-half nail in a case of pellagra. Eur J Dermatol 2006;16:695-6. 
Copyright 2017 BMJ Publishing Group. All rights reserved. For permission to reuse any of this content visit http://group.bmj.com/group/rights-licensing/permissions.

BMJ Case Report Fellows may re-use this article for personal use and teaching without any further permission.

Become a Fellow of BMJ Case Reports today and you can:

- Submit as many cases as you like

- Enjoy fast sympathetic peer review and rapid publication of accepted articles

- Access all the published articles

- Re-use any of the published material for personal use and teaching without further permission

For information on Institutional Fellowships contact consortiasales@bmjgroup.com

Visit casereports.bmj.com for more articles like this and to become a Fellow 